\title{
Research of Application Possibilities of Selected Mechanically Alloyed Metal Powders
}

Jan Novotný, Irena Lysoňková, Štefan Michna, Nataša Náprstková

Faculty of Production Technology and Management, J. E. Purkyne University in Usti nad Labem. Pasteurova 3334/7, 400 01 Usti nad Labem. Czech Republic. e-mail: novotny@fvtm.ujep.cz, lysonkova@fvtm.ujep.cz, cais@fvtm.ujep.cz,michna@fvtm.ujep.cz

Paper is interested in the study of basic theoretical knowledge from the problems of preparation of nanoparticles and microparticles and their mechanical synthesis. Also, the possibility of producing of new materials by mechanical alloying of metal powders evaluation of these newly created materials from the point of morphology and surface condition, as well as physical (eg. electrical charge) and chemical (surface treatment).

Keywords: Mechanical joining, mechanical alloying, mechanical milling, morphology, surface condition, particle, grinding medium, grinding vessel.

\section{References}

[1] BHUSHAN, B. (2003). Springer handbook of nanotechnology, Springer, 2003. ISBN 978-3-642-02525-9.

[2] GIACOVAZZO, C. (2002). Fundamentals of Crystallography, Oxford University Press, USA 2002.

[3] KEJZLAR, P. (2012). Structure and mechanical properties of Fe-25Al-5Zr and Fe-30Al-5Zr intermetallic alloys. Manufacturing Technology, Ústí nad Labem 2012 Voume 12. ISSN 1213-2489

[4] LYSONKOVA, I., NOVOTNY, J.,CAIS, J., MICHNA, S. (2016). Effect of addition of nanoparticles TiO2 into PTFE coating, In Engineering for Rural Development, 2017 Vol. 16, Latvia, pp. 26-30, 2017, ISSN 1691-5976

[5] MÜLlER, M. (2017). Effects of Aluminium Microparticles and Surface Treatment of AlCu4Mg on Mechanical Properties of Adhesive Bond Strength, In Manufacturing Technology, Vol. 17, No. 1, FVTM UJEP, Ústí nad Labem, pp. 66-71. ISSN 1213-2489

[6] NOVOTNY, J., JASKEVIC, M. (2015). Morphology and producing of TiO2 particles, Engineering for Rural Development, 2016 Vol. 15, Latvia, 2015, ISSN 16913043

[7] NOVOTNY, J., JASKEVIC, M., CAIS, J. HUNG T. D. (2016) The shape and structure of titanium dioxide nanoparticles, In Manufacturing Technology, Vol. 16, No. 5, FVTM UJEP, Ústí nad Labem, pp. 1102-1106. ISSN 1213-2489

[8] SURYANARAYANA, C. (2001). Mechanical alloying and milling, Department of Metallurgical and Materials Engineering, Colorado School of Mines, Golden, USA, 2001. ISBN 978-0-8247-4103-7.

[9] VALAŠEK, P., MULLER, M. (2012). Polymeric particle composites with filler saturated matrix. Manufacturing Technology, Ústí nad Labem 2012 Voume 12. ISSN 1213-2489

[10] WEISS, V., STRIHAVKOVA, E. (2012). Influence of the homogenization annealing on microstructure and mechanical properties of AlZn5,5Mg2,5Cu1,5 alloy. Manufacturing Technology, Ústí nad Labem 2012 Voume 12. ISSN 1213-2489

[11] ŽÁRSKÁ, S. (2017). Výzkum možností aplikací vybraných mechanicky legovaných kovových prášků, Bakalár̆ská práce, FVTM, UJEP, Ústí nad Labem, 2017 